\title{
FORAGING ACTIVITY OF THE MEXICAN LEAFCUTTING ANT ATTA MEXICANA (F. SMITH), IN A SONORAN DESERT HABITAT (HYMENOPTERA, FORMICIDAE)
}

\section{A. MINTZER}

Division of Biological Sciences, The University of Michigan Ann Arbor, Michigan 48109 U.S.A.

Reçu le 5 décembre 1978.

Accepte le 15 avril 1979.

\section{SUMMARY}

The largest ant colonies in the North American desert are produced by the Mexican leafcutting ant, Atta mexicana (F. Smith), in northern Sonora. The foraging behavior of A. mexicana is described for the first time. The ants use a system of tunnels and trails extending outward from the nest to reach target vegetation. Over the combined study periods from 1974 to 19777 , one colony collected material from a total surface area of about $8,000 \mathrm{~m}^{2}$. The ants selectively attacked two species of winter annual plants and repeatedly utilized four perennials, two Cercidium spp., Sapium biloculare (S. Wats.), and Larrea tridentata Coville when the annuals were absent. In addition to fresh vegetation, they also collected dry material. The leafcutting behavior of the ants is variable, depending on the size and form of the plant material utilized. The ants foraged during the daytime in winter and spring but became largely nocturnal in summer.

\section{ZUSAMMENFASSUNG}

Futtersammelaktivität der Mexikanischen Blattschneiderameise Atta mexicana (F. Smith) in der Sonora Wüste

Die grössten Ameisenkolonien in der nordamerikanischen Sonora Wüste bildet die mexikanische Blattschneiderameise Atta mexicana, deren Futtersammelaktivitäten erstmalig beschrieben werden. Zum Futtersammeln benutzen diese Ameisen ein System aus Tunneln und Strassen, das vom Nest zu der Vegetation führt. Die Hauptbeobachtungskolonie wurde während mehrerer Jahre in den Monaten Dezember, Januar, März und Juli/August insgesamt 24 Tage lang kontrolliert. Sie sammelte während dieser Zeit Pflanzenmaterial auf einer Grundfläche von etwa $8000 \mathrm{~m}^{2}$. Die Ameisen schnitten bevorzugt zwei annuale Pflanzenarten, nahmen aber, wenn diese fehIten, auch mehrere Arten von perennierenden Pflanzen an. Zusätzlich zu frischen wurden auch trockene Pflanzenteile eingetragen. Das Schneideverhalten der Ameisen war variabel und hing von Grösse und Form der Pflanzen ab. Die Ameisen sammelten in Winter und Frühling tagsüber und gingen im Sommer weitgehend $\mathrm{zu}$ nächtlicher Sammelaktivität über. 


\section{INTRODUCTION}

Fungus culturing ants of the genus Atta are conspicuous insects in most neotropical ecosystems and are serious pests in many areas (WEBER, 1972). The ants collect large amounts of living vegetation as substrate for the fungus upon which they feed. The genus is widely distributed in tropical forest and savanna areas in South and Central America. Two species, Atta texana (BUCKLEY) and Atta mexicana (F. SMITH), have ranges extending northward to the southern border of the United States. A. texana occurs along the Gulf of Mexico in Tamaulipas, Mexico, and in eastern Texas and Louisiana (MoSER, 1967). A. mexicana ranges from Guerrero, Mexico to Arizona in the north (BYARs, 1949). A. mecixana spans a range of habitats from Veracruz rain forest to the Sonoran Desert, at elevations from sea level to over 2000 meters (SMITH, 1963).

Despite its unique distribution over a wide variety of environments, detailed literature on the field behavior of A. mexicana is absent. Comparative studies on foraging behavior of the Mexican leaf- cutter in a variety of habitats with differing vegetation type may be valuable from an ecological and economic perspective. This paper provides initial data on desert foraging behavior of $A$. mexicana. The temperature range of foraging activity, selection of substrate vegetation and leaf cutting behavior were studied in winter, spring and summer.

\section{PROCEDURE}

Observations 'were conducted on colonies located along Mexico highway route two in northern Sonora. . One colony (A) located $46 \mathrm{~km}$. south of Sonoita, Sonora was the primary focus of study. This colony was examined in late December 1974-1976, in March 1975 and 1977, and on July 31 - August 1, 1975 (a total of 24 days). Seven other colonies were also located $24-46 \mathrm{~km}$. south of Sonoita; one of these was nearly one $\mathrm{km}$. from the 'roadside. The elevation in the study area ranged from approximately 400 to $500 \mathrm{~m}$. The mean annual rainfall in the area is approximately $250 \mathrm{~mm}$., based on records at the Organ Pipe Cactus National Monument visitor center, $10 \mathrm{~km}$. north of Sonoita (1). Some prominent perennial plants in this study area included creosote bush (Larrea tridentata Coville), palo verde (Cercidium floridum Benth. and C. microphyllum (Torr.), ironwood (Olneya tesota Gray), mesquite (Prosopis velutina Woot.), Encelia farinosa A. Gray, Condalia globosa Johnst., cholla (Opuntia spp.), senita (Lophocereus schottii (Engelm.) and sahuaro cactus (Carnegia gigantea (Engelm.). The large perennial Sapium biloculare

(1) National Weather Service records at the visitor center (elevation $400 \mathrm{~m}$ ) for 1949. 1973 inclusive. 
(S. Wats.) was abundant in the vicinity of the northernmost colonies. We found 16 other ant species within the foraging area of colony A.

Ants carrying forage items were field collected and later measured with a calibrated ocular reticule under a dissecting microscope. During field counting, ants were arbitrarily classified as large, medium or small. Specimens of plant species attacked by the ants were collected for subsequent identification. In 1976 and 1977, ant trail routes were measured, and the linear distance from tunnel openings to the central nest was also determined for two colonies. The distances from these two colonies to individual plants of preferred perennial species was also measured. Air temperatures were recorded and soil exposure to sunlight was noted during foraging activity.

\section{RESULTS}

\section{Spatial distribution of nests and foraging activity}

The central nest area of the A. mexicana colonies contained extensive accumulations of excavated soil in the form of craters, and large surface refuse piles of exhausted fungal substrate. The primary colony studied was located on the side of a small desert wash, and most other colonies were also situated near or on the margins of arroyos, on otherwise level ground. Foraging trails issued from a system of subsurface tunnels extending outwards from the central nests. The tunnels had surface openings $10-60 \mathrm{~m}$. from the central nest area (fig. 1), and one appeared to extend under the paved highway from the nest of colony A. Tunnels were stable components in the foraging system; many tunnel openings used in December 1975 were still in use 15 months later. The ants foraged along the wash and highway, as 'well as in the open desert. Colony $A$ foraged over a combined surface area of about $8000 \mathrm{~m}^{2}$ during the study periods in 1975, producing several trails simultaneously (2). At the height of activity in March 1975, this colony produced 23 basal foraging trails, some of which produced auxiliary branches. The other colonies observed foraged in a similar manner over large surface areas. In general, the ants adhered to fixed, well worn paths during each study period, although a few trails 'were more transient and disappeared or shifted position. Short surface trails (about $10 \mathrm{~m}$. in length) were common; the longest trail observed extended $70 \mathrm{~m}$. At the terminus of the trails, the ants dispersed and foraged individually, or climbed into vegetation. The great majority of ants on the trails were media workers, but some submajors and a few majors were also observed (Table I).

(2) Colony foraging area was determined using a minimum convex polygon with vertices taken as the distal terminations of foraging trails. 

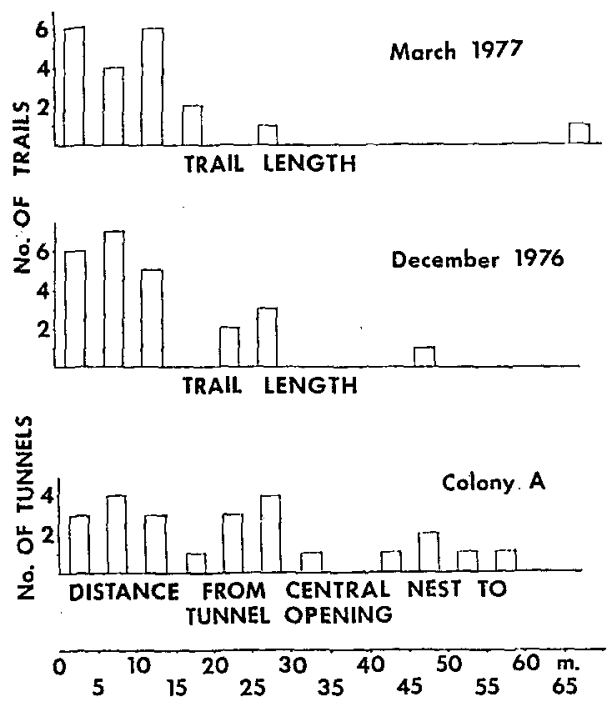

Fig. 1. - Minimum tunnel lengths and surface trail lengths for colony $\mathbf{A}$.

Abb. 1. - Die kleinstmögliche Länge der Tunneln und Strassen von Kolonie A.

Table I. - Ants counted in a trail (30 December 1974). The workers of A. mexicana are highly polymorphic, with body length ranging from $2 \mathrm{~mm}$. (minors) to $12 \mathrm{~mm}$. (majors or soldiers).

Tabelle I. - Zahl von der Ameisen auf einer Sammelaktivitäts-Strasse (30 Dezember 1974).

\begin{tabular}{lcccc}
\hline & Minors & Medias & Submajors & Majors \\
\hline $\begin{array}{l}\text { Ants returning during } \\
\text { a five minute period }\end{array}$ & 0 & 22 & 1 & 0 \\
$\begin{array}{l}\text { Ants returning } \\
\text { with forage items } \\
\begin{array}{l}(5 \text { min) } \\
\text { Ants returning }\end{array}\end{array}$ & 0 & 37 & 1 & 1 \\
with forage items & & & & \\
$\begin{array}{l}10 \text { min) } \\
\text { - large items }\end{array}$ & 0 & 11 & 1 & 0 \\
- medium items & 0 & 26 & 1 & 0 \\
- small items & 0 & 17 & 0 & 0 \\
\hline
\end{tabular}

\section{Time, temperature, and foraging activity}

In December 1974 and 1975 colony A foraged during the daylight hours. The daily maximum air temperatures ranged from 15 to $21^{\circ} \mathrm{C}$. Foraging began when the air temperature exceeded $12^{\circ} \mathrm{C}$ in the morning (0900-1100 hrs.) 
and activity was first noted on trails exposed to the morning sun. Foraging continued into the afternoon until the temperature dropped to $14^{\circ} \mathrm{C}$, when leaf- cutting stopped and the workers returned to the tunnels before the air temperatures dropped below $11^{\circ} \mathrm{C}(1500-1800 \mathrm{hrs}$.). Ants remaining on the shaded surface exposed to an air temperature of $9.5^{\circ} \mathrm{C}$ were immobilized. Overnight freezing temperatures in winter will kill ants exposed on the surface (Mintzer, unpublished observation), but $A$. mexicana can forage during the afternoon on most winter days. The ants were actively collecting leaves at $14^{\circ} \mathrm{C}$ on an overcast day in late December 1975. In late December 1976 , light rainfall did not interrupt foraging in progress.

In late March 1975, colony A was active during the day. On two days of clear skies, activity slackened on most trails in the early afternoon. Traffic ceased between 1400 and $1515 \mathrm{hrs}$. on the most insolated trails, as the ants returned to the nest during the warmest part of the day (about $26^{\circ} \mathrm{C}$ air temperature). On March 28 , the sun was obscured during the early afternoon and foraging continued without interruption until observation ended at sunset. On six clear days in late March 1977, daytime maximum air temperatures ranged from $27-29^{\circ} \mathrm{C}$. Colony A foraged in the morning and late afternoon. Traffic was interrupted between 1100 and $1600 \mathrm{hrs}$. on trails exposed to the sun, but continued through the midday hours on shaded trails. On two overcast days (March 25-26) foraging continued during the midday hours until interrupted by brief heavy rainshowers.

The ants foraged during the evening on July 31,1975 , when the daytime maximum temperature was $39^{\circ} \mathrm{C}$ at the Organ Pipe Cactus National Monument visitor center ( $56 \mathrm{~km}$. north of colony A), a very typical value for July and August (3). The colony produced two large trails after sunset ( $2007 \mathrm{hrs}$.) as the air temperature dropped below $32^{\circ} \mathrm{C}$. At 0730 on August 1, the ants were still active at a reduced level on the two trails. By 0816, the air temperature was $29^{\circ} \mathrm{C}$ and the few remaining ants were all returning to the tunnels. The trails were vacant by 0835 as the temperature reached $32^{\circ} \mathrm{C}$.

\section{Selection of vegetation as substrate}

Perennial plants. Foraging trails extended to the base and up the trunk of target perennial plants. The ants climbed the branches into the crown; at any one time nearly all of the cutting ants were concentrated in one or two small areas in the leaf zone. The relative abundance of utilized perennial species varied greatly from one colony to another (Table II). The A. mexicana colonies cut material most frequently from creosote bush, Larrea tridentata. With two exceptions, all colonies were utilizing this resource during every observation period in December and March. The ants cut and collected the

(3) National Weather Service records at the visitor center (elevation $400 \mathrm{~m}$ ) for 1949 . 1973 inclusive. 
Table II. - Counts of utilized perennial plant species within $50 \mathrm{~m}$. of two A. mexicana colonies in northern Sonora. Plants measured $>70 \mathrm{~cm}$. tall $\left(7854 \mathrm{~m}^{2}\right.$ area).

Tabelle II. - Zahl der benutzenden perennierenden Pflanzenarten (höhe $>70 \mathrm{~cm}$ ) bis auf $50 \mathrm{~m}$. von, zwei Kolonien.

\begin{tabular}{cccccc}
\hline Colony & $\begin{array}{c}\text { Larrea } \\
\text { tridentata }\end{array}$ & $\begin{array}{c}\text { Olneya } \\
\text { tesota }\end{array}$ & $\begin{array}{c}\text { Cercidium } \\
\text { floridum }\end{array}$ & $\begin{array}{c}\text { C. } \\
\text { microphyllum }\end{array}$ & $\begin{array}{c}\text { Sapium } \\
\text { biloculare }\end{array}$ \\
\hline A & 216 & 4 & 6 & 8 & 1 \\
D & 21 & 8 & 0 & 25 & 31 \\
\hline
\end{tabular}

inflorescences available on Larrea in addition to leaves in March 1977. Trails and tunnel openings were frequently littered with cut items from creosote bush. In December 1975, the two species of palo verde, Cercidium microphyllum and C. floridum, had leaves and were attacked by colony $\mathrm{A}$ and other colonies in the local area. In December 1976 and January 1977, colonies near palo verdes (C. microphyllum) with leaves were utilizing this resource. The ants also cut leaves from ironwood (Olneya tesota) during observation periods in December 1975, 1976 and in January and March 1977, although this plant was the least common large perennial around the Atta colonies. In January 1977, colony D (24 km. south of Sonoita) was cutting material from Sapium biloculare, which was locally abundant around this colony. Other colonies in the vicinity 'were also utilizing this plant. In March 1977 colony D ignored Sapium biloculare and collected Larrea leaves and dry vegetation instead. Mesquite (Prosopis sp.) and desert mistletoe (Phoradendron sp.) were attacked less frequently. The most abundant perennial in the vicinity of all colonies was Franseria dumosa. This small plant (usually under $50 \mathrm{~cm}$. in height) occurred at an estimated average density of three individuals $/ \mathrm{m}^{2}$, and was never attacked by Atta. Another common perennial, Encelia farinosa, 'was also avoided during all observation periods. Other perennial plants avoided were Condalia globosa and Ambrosia ambrosioides Cav.

Annual plants. In late March 1975 colony A was utilizing two species of annuals, Plantago insularis Eastwood, and a mallow Sphaeralcea ambigua Gray. $P$. insularis was an abundant small plant (usually under $10 \mathrm{~cm}$. in height) which the ants attacked individually. S. ambigua, a larger plant (up to $50 \mathrm{~cm}$. in height) was selectively attacked by the leafcutters, which left nearby conspecifics untouched. Few of the workers climbed more than $20 \mathrm{~cm}$. in the vegetation, and flowering parts, stem sections and leaves were cut and collected by the ants. Media, submajor, and major workers were observed cutting vegetation. Major workers, the largest foragers, did not collect items of correspondingly large size, but often carried thick items such as inflorescenses of Plantago. The ants appeared to ignore the perennial plants in the vicinity at this time. In 1975, no substantial winter precipitation was recorded until late December. The preferred annual species were represented 
by small and widely scattered specimens, and the ants did not utilize them. In December 1976 and March 1977, annuals were utilized in addition to perennial plants, and inflorescenses of Plantago insularis comprised a major fraction of forage items collected by colony $\mathrm{A}$ in March.

Dry dead vegetation. Dry vegetation was usually collected on the ground surface by individual foragers, although pieces were occasionally cut from dead standing vegetation. Foraging trails utilizing dry vegetation typically had a diffuse terminus, as the ants scattered and foraged individually. Colony A collected dry vegetation during periods in December 1975 and 1976, March 1977 and on July 31 - August 1, 1975. Colony D collected dry vegetation during January and March 1977. Dry leaves dropped by preferred perennial plant species comprised a major fraction of material collected. In December 1976 several trails from colony A collected dry leaflets of Larrea tridentata on the ground surface. In March 1977, two trails from colony D were collecting dry leaflets dropped beneath Cercidium microphyllum.

Leafcutting activity. Atta mexicana shows great variation in leafcutting behavior on different types of vegetation. In nearly all cases, the leafcutters stand on the piece they are attempting to slice off. The ants cut large semicircular leaf segments from large-leaved plants such as citrus, mango, and oleander in cultivation at Alamos in southern Sonora. On narrow bladed annuals such as Plantago insularis, the cutting workers are nearly always oriented proximally, towards the base of the leaf, stem, or plant. The ants usually step over onto the remaining leaf surface as they complete cutting and pull the cut section free. The ants rarely cut pieces of a size smaller than they can stand on, and the pieces are often much larger than the foraging workers.

A different cutting behavior is observed on microphyllous desert perennials such as creosote bush and palo verde, which is similar to that described by Gamboa (1975) in Acromyrmex versicolor in Arizona. Most of these large desert perennials have small compound leaves connected to the stem by a petiole or rachis. The ants climb onto the small leaves and cut them at this convenient narrow junction. A. mexicana workers on palo verde can sever the rachis in about one minute, and often carry back an intact compound leaf cut through the petiole. The cutting ants tend to face towards the stem node, and stand at least partially astride the leaf. Of 151 cutting ants observed on four species of perennials and annuals, only 14 were oriented distally, towards the apex of the leaves or stem.

\section{DISCUSSION}

In terms of biomass per individual colony and numerical size, A. mexicana probably exceeds all other desert inhabiting ant species in North America. 
The Mexican leafcutting ant does not require a highly productive mesic ecosystem such as tropical rain forest in order to produce large colonies which are characteristic of the genus Atta. Although the colonies and their foraging areas are very large and conspicuous in the study areas, the colonies are widely scattered (foraging areas of different colonies are usually not contiguous), and the ant is uncommon or absent in many parts of Sonora.

The deep nests are well adapted to moderating desert extremes of temperature and moisture. The periods of foraging are largely determined by trail solar exposure and ambient temperature. The ants forage during the daytime in the winter months, and are active at night in summer, and their surface activity periods and temperature thresholds are similar to those of Acromyrmex versicolor (GAmBOA, 1976). Atta uses trail pheromones to organize foraging, allowing it to continue or initiate this activity in darkness (MOSER, 1967). Temperature extremes probably preclude continuous surface activity on a 24 hour schedule during most of the year; at Organ Pipe Cactus National Monument, average minimum air temperatures are $11^{\circ} \mathrm{C}$ or below during six months (November-April) and average daily maxima exceed $30^{\circ} \mathrm{C}$ during six months (May-October) (1). Atta mexicana is less tolerant of high surface temperatures in spring and summer than sympatric Pogonomyrmex species in Sonora. The use of long tunnels as a major component of foraging activity is characteristic of A. mexicana. The tunnels extend down at least $30 \mathrm{~cm}$. before turning laterally, approximately parallel to the ground surface. These extensive tunnel systems reduce the exposure of the foraging ants to desiccation and temperature extremes at the airsoil interface, and place them effectively closer to the target vegetation which they must harvest during limited periods of surface activity each day. The initial construction of the tunnels probably requires a considerable energy investment by the ant colony, but the long term returns from harvesting additional resources over an enlarged surface area may be large. In southern Sonora and Tamaulipas, Mexico, A. mexicana colonies in scrub pasture and rangeland also produce foraging tunnels. It is interesting to note that foraging tunnels are encountered in A. texana in eastern Texas and Louisiana (MINTZER, unpub. observations; MOSER, 1967), but are poorly developed or nonexistent in the Costa Rican forest species A. cephalotes (L.) and A. colombica Guer. (L. Rockwood, pers. comm.). Foraging tunnels appear to be a response to daily temperature extremes in the temperate zone and poorly shaded environments in Mexico.

When the preferred winter annual species were abundant, the colonies in northern Sonora did not utilize the perennial species. These ephemeral plants are a preferred winter food resource for A. mexicana in the Sonoran Desert. Desert winter annuals usually germinate after rains in December or January, mature slowly, and flower from March until May (SHREve and 
WIGGINS, 1964). The perennials are attacked before the annuals appear in winter. In the tropics, A. cephalotes also prefers soft, younger foliage (CherReTT, 1973). A second group of annual species germinates after rains in July, August, and September, but the colony observed briefly in summer was not preferentially utilizing this resource. More observations on forager selection of midsummer desert vegetation are needed. Very few herbivores feed on creosote bush, and A. mexicana and its fungal partner appear to be utilizing a resource exploited by few other desert insects. Recent advances in biochemical technique (BOYD and MARTIN, 1975) may allow investigation of relationships between plant secondary compounds and choice of vegetation as substrate by the ants. Although the ants utilize some plants which are inedible or toxic to vertebrates (e.g. Nerium oleander L.), they are selective and completely ignore some common plants around their nests; presumably they are avoiding vegetation containing substances toxic to fungal enzymes and metabolism.

AckNowLEDGEMENTS. - The author was supported by a N.S.F. Graduate Fellowship and a travel allowance from the University of Michigan Graduate School during field work in December 1976 and 1977. I am greatly indebted to Barry PULLEN for his valuable assistance at the primary study site in Mexico. I thank Gordon Marsh of the Museum of Systematic Biology, University of California at Irvine for determination of the desert annuals, and for kindly reviewing an early draft of this manuscript. I also thank G.L. HunT and R. BERKElHAMER at U.C. Irvine and M.M. MARTIN and D. JanZEN for constructive criticisms of this paper.

\section{Literature cited}

Boyd N.D., MARTIN M.M., 1975. - Faecal proteinases of the fungus- growing ant, Atta texana: properties, significance and possible origin. Ins. Biochem., 5, 619-635.

ByarS L.F., 1949. - The Mexican leaf- cutting ant in the United States. J. Econ. Ent., $42,545$.

Cherretr J.M., 1973. - Some factors involved in the selection of vegetable substrate by Atta cephalotes (L.) in tropical rain forest. J. Anim. Ecol., 41, 647-660.

Gamboa G., 1975. - Foraging and leaf- cutting of the Desert Gardening Ant Acromyrmex versicolor (Pergande). Oecologia, 20, 103-110.

GAMBOA G., 1976. - Effects of temperature on the surface activity of the desert leafcutter ant, Acromyrmex versicolor (Pergande). Am. Mid. Nat., 95, 485-491.

MoSER J.C., 1967. - Trails of the leafcutters. Nat. Hist., 76, nr. 1.

SHREVE F., WrgGINS I.L., 1964. - Vegetation and flora of the Sonoran Desert. Stanford University Press, edit., Stanford, $\mathrm{Ca}, \mathrm{X}+1673 \mathrm{p}$.

SMITH M.R., 1963. - Notes on the leaf-cutting ants, Atta spp., of the United States and Mexico. Proc. Ent. Soc. Wash., 65, 299-302.

Weber N.A., 1972. - Gardening Ants, the Attines. Mem. Am. Philo. Soc. Philadelphia, 92. 